\title{
JESSNERS LYMPHOCYTIC INFILTRATION OF SKIN SUCESSFUL TREATMENT WITH PREDNISOLONE AND HYDROXY CHLOROQUINE
}

\author{
P. Guru Prasad1, Indira Bonthu², R. Rama33, B. T. V. N. Raju4 ${ }^{4}$ B. Durga Bhavani ${ }^{5}$
}

\section{HOW TO CITE THIS ARTICLE:}

P. Guru Prasad, Indira Bonthu, R. Rama, B. T. V. N. Raju, B. Durga Bhavani. "Jessners Lymphocytic Infiltration of Skin Sucessful Treatment with Prednisolone and Hydroxy Chloroquine". Journal of Evolution of Medical and Dental Sciences 2015; Vol. 4, Issue 04, January 12; Page: 724-728, DOI: 10.14260/jemds/2015/105

ABSTRACT: Jessners lymphocytic infiltration of the skin is a chronic, benign T-cell infiltrative disorder, usually manifesting as erythematous papules or plaques on the face, neck and back. we report the case of a 66- year - old man, who presented with erythematous papules and plaques on nose of 4 months duration and erythematous plaque on right arm of 1 month duration. skin biopsy confirmed the diagnosis of jessner's lymphocytic infiltration of the skin.The evolution was favorable with hydroxy chloroquine and prednisolone.

KEYWORDS: Jessners lymphocytic infiltration of skin, hydroxy chloroquine and Prednisolone.

INTRODUCTION: Jessner's lymphocytic infiltration of the skin (JLIS) is a skin condition of unknown aetiology characterized by erythematous papules and plaques located on the head, neck and upper back. The eruption resolves spontaneously after months or a few years but can recur for several years. A variety of empirical treatments has been tried with limited success. Here we report a case of jessners lymphocytic infiltration of skin successfully treated with hydroxychloroquine and prednisolone.

CASE REPORT: A 66 Years old man presented with history of erythematous papules and plaques on the nose of 4 months duration and erythematous plaque on right arm of 1 month duration. The present complaint started as small erythematous lesion $0.5 \mathrm{~cm}$ size on the right lateral aspect of the nose and gradually involved the bridge \& left lateral aspect. There is history of increased erythema and burning sensation on exposure to sunlight. There is no history of oral ulcers, arthralgia. No history of aggravation with intake of spicy foods \& alcohol. No history of loss of weight \& loss of apetite. No history of similar complaints in the past. No history of diabetes mellitus, hypertension, jaundice \& psoriasis. He is a known alcoholic and smoker since 30 years.

He is moderately built \& moderately nourished, no cyanosis, no clubbing, no jaundice, no generalized lymphadenopathy.

Cutaneous examination showed well defined erythematous infiltrated plaque, few erythematous papules at the margins over the nose. well defined erythematous infiltrated plaque of $3 \mathrm{x} 2 \mathrm{~cm} 2$ size on the medial aspect of upper $1 / 3^{\text {rd }}$ of the right arm. Oral cavity, nails, palms \& soles were normal.

Differential diagnosis of tumid DLE, Jessners lymphocytic infiltration of the skin, polymorphic light eruption, sarcoidosis and rosacea (Rhinophyma ) were considered.

Haematological investigations, renal, liver \& thyroid function tests, borrelia serology, screening for ANA was done.All are with in normal limits.skin biopsy was taken.

Histopathological findings showed epidermis is of variable thickness with flattened reteridges, orthokeratosis and increased basal pigmentation. 


\section{CASE REPORT}

Pappilary \&reticular dermis shows diffuse dense inflammatory cells comprising predominately of small lymphocytes \& few plasma cells. No epidermatropism, no granulomas.

Direct immunoflurosence negative

Mantoux - 7 mm induration

Chest $x$ ray was normal

CT scan of thorax and abdomen was normal expect mild prostatomegaly.

Bone marrow examination showed reactive changes with slight leucocytosis.

Basing on history, clinical features and histopathological findings diagnosis of jessners lymphocytic infiltration of the skin was made.

After confirming the diagnosis, we put the patient on Tab. Hydroxy chloroquine $200 \mathrm{mg}$ BID tapered over a period of 6 weeks and Tab. prednisolone 20mg daily for 4 weeks along with topical sunscreen.

Skin lesions subsided after 6 weeks treatment was stopped and the patient was followed up for 1 year. There was no recurrence of the lesions till now.

DISCUSSION: JLIS, described by Jessner \& Kanof in 1953,(1) is known as a benign chronic T-cell infiltrative disorder with lesions persisting for several months or years. Spontaneous remission may be seen, but JLIS has a tendency to relapse.

The incidence of JLIS is unknown, but it is considered uncommon. It mostly affects middleaged adults, with equal incidence in men and women, and very rarely occurs in children. ${ }^{(2,3)}$ Familial occurrence has been described in the literature. ${ }^{(4,5)}$ In our case patient is an elderly male presenting for the first time.

JLIS is characterized by single or multiple erythematous papules or plaques and, less commonly, nodules, typically localized on the face, neck, chest, arms and upper back.(3) Our case also presented with similar features.

Sometimes an arciform configuration with central clearing is seen. Usually the lesions are asymptomatic, but they can be itching or burning. The relationship to sun exposure is variable and there is no regional variation in incidence.(3) In our case history of aggravation on exposure to sunlight is present.

Whether JLIS is a separate entity, or belongs to the disease spectrum of cutaneous lupus erythematosus or polymorphous light eruption is still a matter of debate, since clinical and histopathological features may overlap in particular with lupus erythematosus tumidus. Recent comprehensive studies conclude that these two conditions share more similarities than differences.(2,6) A few cases related to Borrelia burgdorferi infection or drugs have been reported.(78) Also, a few cases have been ascribed to contact allergy.(9)

Histopathologically JLIS is characterized by a superficial and deep, primarily perivascular, sleeve-like lymphocytic dermal infiltrate with a predominance of small mature polyclonal lymphocytes and without epidermal involvement.(2,10) Deposits of mucin in the reticular dermis have been described.(6) However, other authors have been unable to demonstrate mucin in JLIS. $(2,11)$ in our case histopathology is in corealation with previous studies.

A variety of treatments has been tried, with variable, and often limited, success, including topical, intra-lesional or systemic corticosteroids, antimalarials, thalidomide, tetracyclines, cryotherapy and photo-protection. A few cases of successful treatment with dapsone, auranofin, and 


\section{CASE REPORT}

chemotherapy have been reported.(12-14)

In our case there was partial response to hydroxy chloroquine, as patient was a chronic smoker. So this is in concurance with previous studies.(15),(16) So we added prednisolone $20 \mathrm{mg}$ tapered over a period of 4 weeks. Patient is under remission after 6 weeks. 1 year follow up was done, there were no recurrences. Prognosis is good, because lymphocytic infiltration of skin resolves spontaneously.

\section{REFERENCES:}

1. Jessner M, Kanof B. Lymphocytic infiltration of the skin. Arch Dermatol 1953; 68: 447-449.

2. Lipsker D, Mitschler A, Grosshans E, Cribier B. Could Jessner's lymphocytic infiltrate of the skin be a dermal variant of lupus erythematosus? An analysis of 210 cases. Dermatology 2006; 213: $15-22$.

3. Toonstra J, Wildschut A, Boer J, Smeenk G, Willemze R, van der Putte SC, et al. Jessner's lymphocytic infiltration of the skin. A clinical study of 100 patients. Arch Dermatol 1989; 125: 1525-1530.

4. Dippel E, Poenitz N, Klemke CD, Orfanos CE, Goerdt S. Familial lymphocytic infiltration of the skin: histochemical and molecular analysis in three brothers. Dermatology 2002; 204: 12-16.

5. Ashworth J, Morley WN. Jessner and Kanof's lymphocytic infiltration of the skin: a familial variant. Dermatologica 1988; 177: 120-122.

6. Rémy-Leroux V, Léonard F, Lambert D, Wechsler J, Cribier B, Thomas P, et al. Comparison of histopathologic-clinical characteristics of Jessner's lymphocytic infiltration of the skin and lupus erythematosus tumidus: multicenter study of 46 cases. J Am Acad Dermatol 2008; 58: 217-223.

7. Abele DC, Anders KH, Chandler FW. Benign lymphocytic infiltration (Jessner-Kanof): another manifestation of borreliosis? J Am Acad Dermatol 1989; 21: 795-797.

8. Schepis C, Lentini M, Siragusa M, Batolo D. ACE-inhibitor-induced drug eruption resembling lymphocytic infiltration (of Jessner-Kanof) and lupus erythematosus tumidus. Dermatology 2004; 208: 354-355.

9. Caroli UM, Berner D, Schlegel C, Metzler G, Röcken M, Biedermann T. Lymphocytic infiltration of the skin Jessner-Kanof after treatment with a hydroquinone-containing bleaching cream. Arch Dermatol 2006; 142: 1655-1656.

10. Poenitz N, Dippel E, Klemke CD, Qadoumi M, Goerdt S. Jessner's lymphocytic infiltration of the skin: a CD8+ polyclonal reactive skin condition. Dermatology 2003; 207: 276-284.

11. Teixeira M, Ferreira M, Alves R, Selores M. Lupus erythematosus tumidus: an underestimated entity. Lupus 2006; 15: 296-300.

12. Ardavanis A, Orphanos G, Skafida S, Basioukas S, Rigatos G. Coincidential successful treatment of Jessner-Kanof disease with chemotherapy. Ann Oncol 2008; 19: 1360-1361.

13. Rai VM, Balachandran C. Multiple infiltrated nodules and plaques. Lymphocytic infiltrate of Jessner. Dermatol Online J 2006; 12: 26.

14. Hafejee A, Winhoven S, Coulson IH. Jessner's lymphocytic infiltrate responding to oral auranofin. J Dermatolog Treat 2004; 15: 331-332.

15. Hügel R, Schwarz T, Gläser R. Resistance to hydroxychloroquine due to smoking in a patient with lupus erythematosus tumidus. Br J Dermatol 2007; 157: 1081-1083 


\section{CASE REPORT}

16. Rasa Laurinaviciene1, Ole Clemmensen 2 and Anette Bygum $1 *$ Departments of 1Dermatology and 2 Pathology, Odense University Hospital, DK-5000 Odense, Denmark. Successful Treatment of Jessner's Lymphocytic Infiltration of the Skin with Methotrexate *E-mail: anette.bygum@ouh.regionsyddanmark.dk Accepted May 25, 2009.
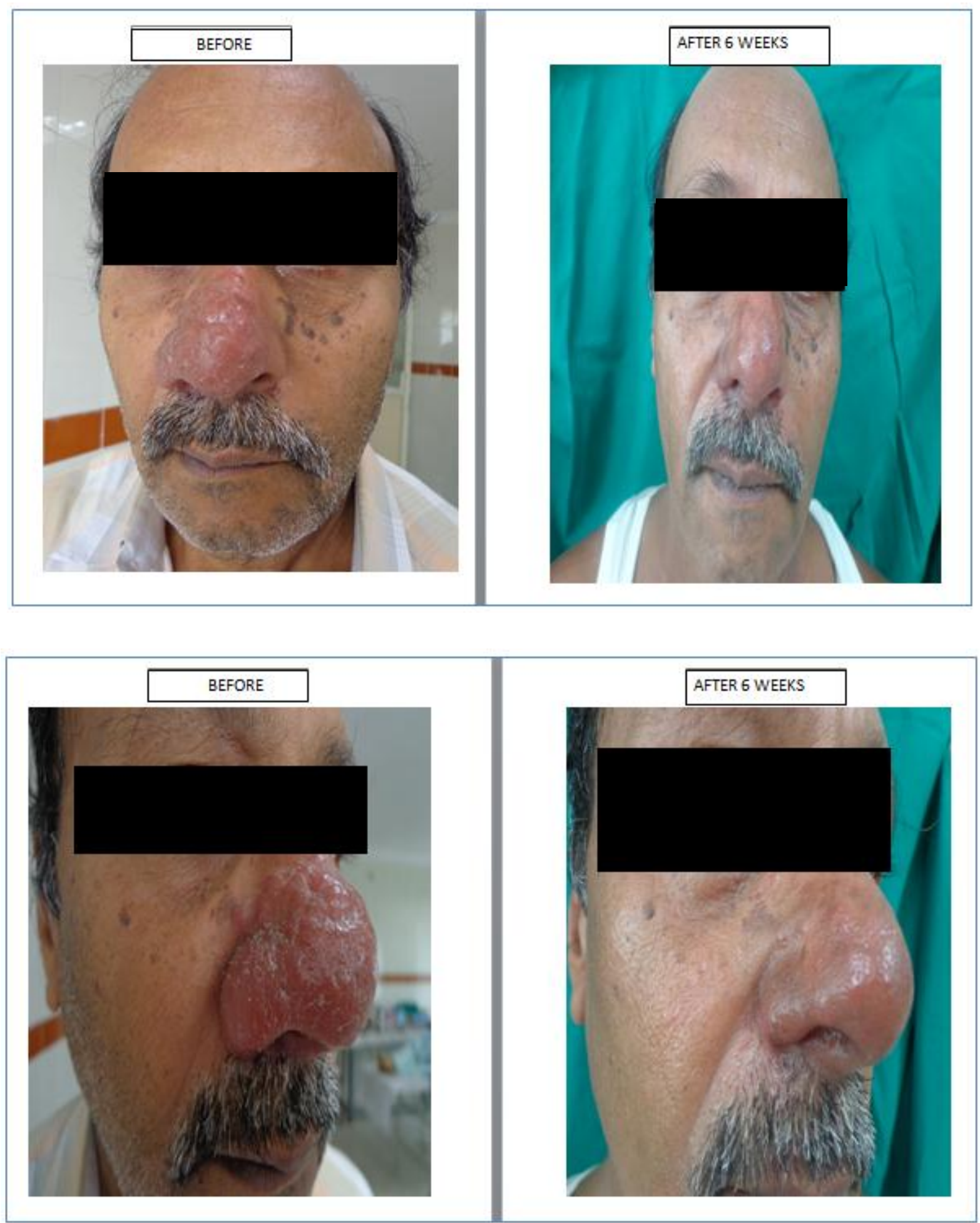


\section{CASE REPORT}

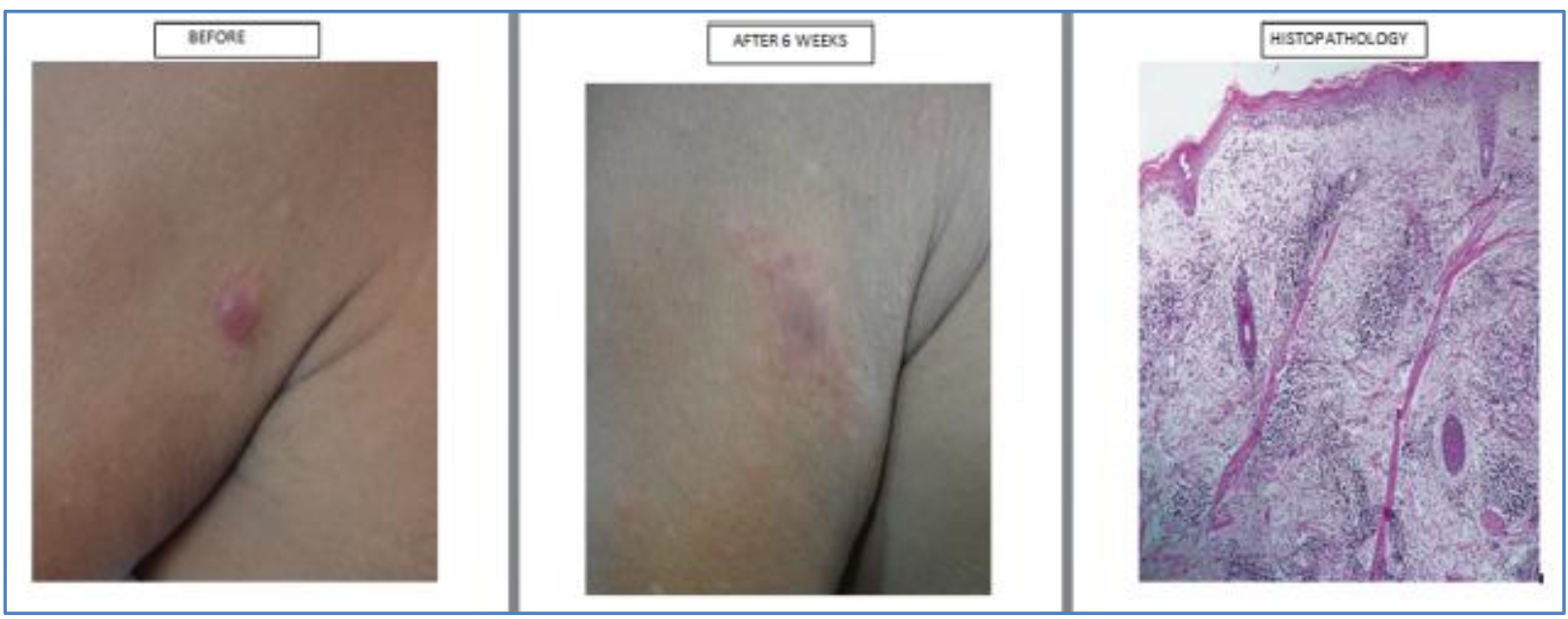

\section{AUTHORS:}

1. P. Guru Prasad

2. Indira Bonthu

3. R. Rama

4. B. T. V. N. Raju

5. B. Durga Bhavani

\section{PARTICULARS OF CONTRIBUTORS:}

1. Professor, Department of Dermatology, Andhra Medical College.

2. Assistant Professor, Department of DVL, Andhra Medical College.

3. Assistant Professor, Department of Dermatology, Andhra Medical College.

4. Assistant Professor, Department of DVL, Andhra Medical College.
5. Junior Resident, Department of DVL, Andhra Medical College.

\section{NAME ADDRESS EMAIL ID OF THE CORRESPONDING AUTHOR:}

Dr. P. Guru Prasad,

Professor,

Department of Dermatology,

Andhra Medical College,

Vizag.

E-mail: gppatnala@yahoo.co.in

Date of Submission: 27/12/2014.

Date of Peer Review: 28/12/2014.

Date of Acceptance: 03/01/2015.

Date of Publishing: 12/01/2015. 